\title{
A latinidade da cirurgia de controle de danos
}

\section{Damage control surgery and latin america's contributions to it}

TCBC-PA Geraldo Roger Normando JR.

$\mathrm{N}$ ão faz muito tempo, e existia a premissa que o paciente cirúrgico seria mais bem tratado se sua operação fosse resolvida em apenas um "golpe". Esse titã era elevado à categoria de "supercirurgião", mesmo se houvesse insucesso. Acontece que novos conceitos opuseramse a essa abordagem e hoje em dia é perfeitamente aceitável que um tipo particular de paciente, aquele com lesões complexas, sangrando aos borbotões e com a vida por um fio possa ser tratado em várias etapas, acrescido de alguns "truques". Na "regra de ouro" prescrita por Descartes seria: "dividir todos os problemas em tantas partes quantas necessárias para resolvê-las e conduzir ordenadamente, dos mais simples para os mais complicados" Nos dias de hoje, com a rapidez pré-hospitalar e a introdução do "Advanced Trauma Life Support" (ATLS) nas salas de emergência, um número elevado de vítimas chegam e permanecem vivas nas salas de emergência, ainda que em estado crítico. Percebia-se (e ainda se vê...) neste supercirurgião, que não acompanhou este compasso evolutivo do conhecimento, mortalidade que beirava 100\%. Daí sua imagem, então, começou a ficar borrada.

Com o novo prelúdio, o supercirurgião perdeu o prefixo e teve seu nome reduzido a uma segunda imagem: aos que enxergam os pródromos da tríade letal (acidez sanguínea, coagulopatia e hipotermia) com se fosse uma aura. Nela, faz-se mister empregar técnicas simples, rápidas e eficazes para aquele momento. São manobras instituídas na década de 1980 para diminuir a mortalidade das lesões graves, quando se instala pelo menos um dos componentes da tríade. Diante desta percepção clínica, o cirurgião de hoje resolve estrategicamente redirecionar a operação para três tempos, em vez do "apenas um golpe", como na época do "super".

No primeiro tempo realiza apenas "controle" da situação, ou seja, se em alguma parte o encanamento estoura e se coloca o dedo para conter o estorvo do vazamento, ou seja, estanca-se a hemorragia. Para isso basta um acesso abreviado com a menor perda de tempo possível. No caso exemplar do ferimento complexo do fígado, o cirurgião abre o abdome e imediatamente coloca um número suficiente de compressas, ou balão, sobre o ponto de sangramento e fecha a parede.

O segundo tempo, o de "controle clínico", inicia-se logo após a chegada no CTI. O objetivo é corrigir o distúrbio de coagulação, neutralizar a acidez sanguínea e reaquecer o corpo. Estima-se que essa fase dure até 72 horas - não mais - em vista do risco de infecção.
A terceira fase - se o paciente sobreviver - é a "correção definitiva". Ocorre após o desaparecimento da tríade letal. O paciente é reencaminhado à sala de operações para desfazer as manobras heróicas e corrigir o defeito. Estima-se que nesta sequência a mortalidade caia de $100 \%$ para $60 \%$ e até mesmo para $30 \%$, dependendo do estado clínico do paciente e da adequação de cada hospital.

Mas esta não é uma idéia nova. Pringle, em 1908, e depois Halsted, empacotaram o fígado de seus pacientes ao perceberem que não conseguiam coibir sangramentos vultosos. Essa idéia sofreu críticas contundentes do exército americano e não pôde ser levada adiante porque a morte por infecção era certa e o cirurgião o maior culpado.

Em 1979 Calne', cirurgião britânico, por morar em zona rural ressuscitou a idéia de Pringle e Halsted, num clássico exemplo de serendipity (ao acaso). Ele socou compressas no fígado de vítimas graves até conter o sangramento; fechou o abdome e enviou o paciente para um centro equipado com terapia intensiva. Este doente sobreviveu. Depois mais quatro também sobreviveram. Publicou os casos e, a partir daí, renasceu um novo momento, que Stone (1982) cognominou "Laparotomia abreviada" 2 . Reza a lenda que Calne tinha muito receio durante o pós-operatório, por isso enviava seus pacientes para centros mais capacitados.

No início dos anos noventa, Michael Rotondo 3 (Filadélfia, EUA) se aproveitou da idéia de Calne e Stone e substituiu o termo "laparotomia abreviada" por "Cirurgia de Controle de Danos" (Damage control, em inglês), ao estender as medidas para outras vísceras abdominais, tórax, crânio e pescoço, fazendo renascer essa nova pedra filosofal na cirurgia.

A verdade é que o controle de danos, nos moldes de sua preconização, é muito oneroso para os países com gastos limitados com a saúde e com o trauma, mas nem por isso abandonou-se a idéia do que representa essa mudança de pensamento na cirurgia moderna. O texano Keneth Mattox, uma lenda viva da cirurgia, escreveu uma nota sobre o tema, que muito envaidece o cirurgião latino, que s defronta com a realidade de Calne: "O olhar despretensioso de qualquer um sabe apontar para a Bolsa de Bogotá. Ele representa uma das mais significantes mudanças em cirurgia durante os últimos 50 anos. Este conceito de controle de dano documenta um exemplo de visão, coragem e liderança da cirurgia na América Latina." 
A sandice de Mattox é boleada por Varga Llosa, latino detentor do Premio Nobel de Literatura: "O mesmo continente que (...) é a própria encarnação do subdesenvolvimento detém um alto coeficiente de originalidade literária e artística." A Bolsa de Bogotá não é só o máximo da arte do cirurgião latino, mas o exemplo enaltecedor da simplicidade dos que trabalham com o trauma e que necessitam de um corolário de truques onde as condições de trabalho são modestas diante da complexidade da doença trauma, cuja "regra de ouro" descrita por Descartes não poderá, jamais, deixar de ser prescrita.

\section{REFERENCIAS}

1. Calne RY, McMaster P, Pentlow BD. The treatment of major liver trauma by primary packing with transfer of the patient for definitive treatment. Br J Surg. 1979;66(5):338-9.

2. Stone HH, Fabian TC, Turkleson ML. Wounds of the portal venous system. World J Surg. 1982;6(3):335-41.

3. Rotondo MF, Schwab CW, McGonigal MD, Phillips GR 3rd, Fruchterman TM, Kauder DR, Latenser BA, Angood PA. 'Damage control': an approach for improved survival in exsanguinating penetrating abdominal injury. J Trauma. 1993 Sep;35(3):375-82; discussion 382-3. 